\title{
HIBRIDISASI INTERSPESIFIK TIGA SPESIES IKAN TOR (Tor soro, Tor douronensis, DAN Tor tambroides) SECARA RESIPROKAL PADA FASE LARVA
}

\author{
Toni Yulian Kusmardani*), Otong Zenal Arifin ${ }^{* * \#}$, Agoes Soeprijanto*), dan Yunita Maimunah") \\ *) Fakultas Perikananan IImu Kelautan Universitas Brawijaya \\ Jl. Veteran No. 16, Ketawanggede, Kec. Lowokwaru, Kota Malang, Jawa Timur 65145 \\ * Balai Riset Perikanan Budidaya Air Tawar dan Penyuluhan Perikanan \\ Jl. Sempur No. 1, Bogor 16129
}

(Naskah diterima: 27 Agustus 2020; Revisi final: 19 Maret 2021; Disetujui publikasi: 19 Maret 2021)

\begin{abstract}
ABSTRAK
Ikan Tor merupakan genus yang potensi dibudidayakan karena memiliki nilai ekonomis tinggi. Masalah yang ada adalah lambatnya pertumbuhan dan rendahnya tingkat sintasan benih ikan tersebut dalam jumlah yang memadai untuk pembudidaya. Hibridisasi atau persilangan merupakan suatu upaya untuk mendapatkan kombinasi antara populasi yang berbeda untuk menghasilkan keturunan yang memiliki sifat unggul. Hibridisasi tiga spesies ikan Tor secara resiprokal antara Tor soro (Ts), Tor douronensis (Td), dan Tor tambroides ( $\mathrm{Tt}$ ) dilakukan guna untuk mengetahui keberhasilan hibridisasi beda spesies tetapi masih dalam genus. Metode yang digunakan pada penelitian ini adalah eksperimen dengan enam perlakuan dan tiga kali ulangan hasil hibrida. Hasil yang diperoleh menunjukkan nilai derajat pembuahan tertinggi dihasilkan dari hibridisasi Td $><$ Ts $(93,66 \pm 1,15 \%$, daya tetas tertinggi dihasilkan dari persilangan $\mathrm{Td}><\mathrm{Ts}(88,00$ $\pm 1,00 \%$, laju pertumbuhan spesifik bobot tertinggi dihasilkan dari hibridisasi Ts $><\mathrm{Td}$ dan Ts $><\mathrm{Tt}$ $(5,62 \pm 0,17 \% 5,44 \pm 0,06 \%$, laju pertumbuhan spesifik panjang tertinggi dihasilkan dari hibridisasi Ts $><\operatorname{Td}(1,79 \pm 0,11 \%)$ dan sintasan tertinggi dihasilkan dari hibridisasi Tt $><\operatorname{Ts}(86,00 \pm 3,60 \%$. Nilai heterosisyang meliputi derajat pembuahan, daya tetas telur, pertumbuhan benih, dan sintasan ikan sampai umur 41 hari menunjukkan nilai negatif, kecuali laju pertumbuhan spesifik bobot. Hibridisasi berdampak pada meningkatnya jumlah larva abnormal yang dihasilkan dibanding tetuanya (pure breed).
\end{abstract}

KATA KUNCl: hibridisasi; interspesifik; resiprokal; spesies ikan tor; heterosis

ABSTRACT: Interspecific hybridization of tor species (Tor soro, Tor douronensis, and Tor tambroides) reciprocally in the larval phase. By: Toni Yulian Kusmardani, Otong Zenal Arifin, Agoes Soeprijanto, and Yunita Maimunah

Tor fish has the potential to be commercially developed as a farmed fish due to its high economic value and market demand. However, slow growth and low survival rate of the fish larvae and insufficient seed availability for aquaculture farmers are the main bottlenecks to develop a profitable aquaculture for tor fish. Hybridization or crossbreed is an attempt to get a combination between different populations to produce offspring inheriting superior characters. A reciprocal hybridization between Tor soro (Ts), Tor douronensis (Td), and Tor tambroides (Tt) was carried out to assess the success rate of hybridization between the three species. The study used an experimental design with six treatments and three replications to measure and compare hybridization and survival parameters between the species. The highest fertilization rate attained by hybridization $\mathrm{Td}><\mathrm{Ts}(93.66 \pm 1.15 \%$ the highest hatching rate was achieved by $\mathrm{Td}\rangle\langle\mathrm{Ts}(88.00 \pm 1.00 \%$, the highest weight specific growth rate was gained by hybridization Ts $><$ $\mathrm{Td}$ and $\mathrm{Ts}><\mathrm{Tt}(5.62 \pm 0.17 \% 5.44 \pm 0.06 \%$, the highest lenght specific growth ratewas achieved by hybridization $\operatorname{Ts}><\operatorname{Td}(1.79 \pm 0.11 \%)$ and highest survival rate was resulted from hybridization between Tor tambroides $><$

\footnotetext{
\# Korespondensi: Balai Riset Perikanan Budidaya Air Tawar dan Penyuluhan Perikanan

Jl. Sempur No. 1, Bogor 16129, Indonesia

Tel. + 622518313200

E-mail: zenalarifin@gmail.com
} 
Tor tambroides $(90.33 \pm 1.52 \%$ ). The obser ved heterosis (degree of fertilization rate, hatching rate, growth rate, and survival rate until the age of 41 days) showed that all parameter characters were negative, except for the weightspecific growth rate characters. This study concludes that hybridization have an impact on increasing the number of abnormal larvae produced compared to their parents (pure-breed).

\section{KEYWORDS: hybridization; interspecific; reciprocal; tor species; heterosis}

\section{PENDAHULUAN}

Ikan Tor merupakan genus ikan konsumsi yang memiliki potensi nilai ekonomis tinggi. Menurut Radona et al. (2015), Indonesia memiliki banyak ikan lokal yang berpotensi untuk dikembangkan dalam rangka meningkatkan produksi perikanan budidaya dalam mendukung industrialisasi perikanan. Ikan genus Tor merupakan salah satu komo ditas yang potensial dikembangkan dan sangat berpotensi sebagai komoditas yang unggul budidaya air tawar.

Di Pulau Jawa, ikan ini ditemukan di daerah Jawa Barat (Kuningan, Bogor, dan Sumedang) yang dikenal sebagai ikan dewa. Habitat ikan Tor ada di sepanjang aliran sungai dan perairan umum pada dataran tinggi, dengan daerah persebaran meliputi Sumatera, Jawa, Malaysia, Birma, Thailand, dan Indo-Cina. Di Pulau Sumatera harga ikan Tor mencapai dua ratus sampai tiga ratus ribu rupiah per kilogram, dan di pulau Jawa harganya mencapai empat ratus ribu rupiah per kilogram (Qudus et al., 2012).

Permasalahan dalam pembenihan ikan, banyak terkendala pada mutu induk dan juga benih yang dihasilkan. Benih dan induk yang unggul akan meningkatkan keberhasilan dalam budidaya, karenanya berbagai upaya peningkatan mutu perlu terus dilakukan guna peningkatan efisiensi dan produktivitas budidaya yang memiliki daya saing yang tinggi (Yustysi et al., 2016). Hibridisasi adalah proses perkawinan antar individu dari spesies yang berbeda (hibridisasi interspesifik) atau individu genetik berbeda dari spesies yang sama (hibridisasi intraspesifik). Eksploitasi sifat unggul melalui hibridisasi dapat diperoleh melalui mekanisme heterosis, yaitu aksi gen dominansi pada individu heterosigot "hybrid vigour" (Tave, 1995). Hibridisasi antara dua populasi yang berbeda secara genetik lazimnya menghasilkan kombinasi genetik baru (Arifin et al., 2017b).

Hibrida antar-spesies telah dikembangkan untuk meningkatkan laju pertumbuhan, meningkatkan produktivitas melalui kekuatan hibrida, mentransfer sifat-sifat yang diinginkan, mengurangi reproduksi yang tidak diinginkan melalui produksi ikan steril, menggabungkan sifat-sifat ekonomis lainnya seperti kualitas daging yang baik, ketahanan terhadap penyakit dan meningkatkan toleransi lingkungan, konversi pakan lebih baik, memanfaatkan dimorfisme seksual, dan meningkatkan tingkat produksi dalam sistem budidaya. Hibrida memainkan peran penting untuk peningkatan produksi budidaya beberapa spesies ikan air tawar dan laut; misalnya, lele hibrida di Thailand, ikan nila hibrida di Amerika Serikat, nila hibrida di Israel, dan characids hibrida di Venezuela (Rahman et al., 2013). Melalui hibridisasi dapat dihasilkan ikan yang memiliki keunggulan lebih baik dibandingkan dengan tetuanya dalam hal peningkatan kecepatan pertumbuhan, ketahanan hidup, rasio seks, serta penampilan warna. Riset hibridisasi interspesifik spesies ikan Tor (T. soro, T. douronensis, dan T. tambroides) bertujuan untuk mengevaluasi performa pertumbuhan dan nilai heterosis benih hibrid hasil tiga spesies.

\section{BAHAN DAN METODE}

Metode yang digunakan pada penelitian ini yaitu menggunakan meto de rancangan acak lengkap dengan enam perlakuan hasil hibrida dengan ulangan sebanyak tiga kali. Perlakuan yang digunakan terlihat pada Tabel 1.

Pemijahan dilakukan secara buatan melalui penyuntikan dilakukan sebanyak dua kali dengan dosis $0,6 \mathrm{~mL} / \mathrm{kg}$ dari bobot ikan menggunakan gonadotropin merek ovaprim. Penyuntikan pertama sebanyak $0,2 \mathrm{~mL} / \mathrm{kg}$ induk, sedangkan penyuntikan kedua sebanyak $0,4 \mathrm{~mL} / \mathrm{kg}$ induk dengan selang waktu antar penyuntikan selama delapan jam. Stripping dilakukan dengan mengurut dari bagian perut menuju sirip anal hingga telur maupun sperma keluar. Telur dan sperma dicampur untuk terjadi fertilisasi dengan menambahkan air, lalu diaduk perlahan dengan bulu ayam hingga merata. Telur yang sudah dibuahi dari masing-masing perlakuan diambil sebanyak 100 butir untuk masing-masing ulangan penelitian, diinkubasi dan ditetaskan pada media akuarium penetasan.

Pada saat kuning telur habis dilakukan penimbangan dan pengukuran sampel sebagai bobot awal ikan dan ditandai dengan (W 0). Larva selanjutnya diberi pakan nauplii Artemia secara ad-libitum. Untuk mengetahui bobot ikan dilakukan dengan cara menimbang ikan menggunakan timbangan digital dengan ketelitian 0,01 $\mathrm{g}$ dan panjang diukur menggunakan milimeterblock setiap 14 hari ikan sekali. Pada penelitian ini menggunakan teknik random sampling dengan 10\% pengambilan sampel dari objek yang diteliti. 
Tabel 1. Skema hibridisasi dua arah interspesifik spesies ikan Tor (T. soro, T. douronensis, dan T. tambroides)

Table 1. Interspecific reciprocal hibridization schematic of Tor spesies (T. soro, T. douronensis, and $\mathbf{T}$. tambroides)

\begin{tabular}{lcccc}
\hline \multirow{2}{*}{ Spesies (Species) } & \multicolumn{3}{c}{ Jantan (Male) } \\
\cline { 2 - 4 } & & Tor soro $(\mathrm{Ts})$ & Tor douronensis (Td) & Tor tambroides (Tt) \\
\hline \multirow{2}{*}{ Betina } & Tor soro $(\mathrm{Ts})$ & $\mathrm{Ts}><\mathrm{Td}$ & $\mathrm{Ts}><\mathrm{Tt}$ \\
Female & Tor douronensis $(\mathrm{Td})$ & $\mathrm{Td}><\mathrm{Ts}$ & $\mathrm{Td}><\mathrm{Tt}$ \\
& Tor tambroides $(\mathrm{Tt})$ & $\mathrm{Tt}><\mathrm{Ts}$ & $\mathrm{Tt}><\mathrm{Td}$ & \\
\hline
\end{tabular}

Pengamatan derajat pembuahan (FR) dilakukan 56 jam setelah telur dibuahi, ciri telur dibuahi berwarna bening transparan, bentuk bulat dan pada bagian tengah berbentuk bulat kecoklatan. Rumus yang digunakan berdasarkan Effendie (1997):

$$
\mathrm{FR}=\frac{\text { Telur yang dibuahi }}{\text { Total telur }} \times 100
$$

Pengamatan derajat penetasan (HR) dilakukan setelah semua telur menetas. Rumus yang digunakan berdasarkan Effendie (1997):

$$
\mathrm{HR}=\frac{\text { Telur yang menetas }}{\text { Total telur }} \times 100
$$

Tingkat sintasan (SR) dihitung berdasarkan persentase jumlah larva yang hidup pada akhir pengamatan (41 hari) dibandingkan jumlah larva pada awal penebaran di akuarium. Rumus yang digunakan berdasarkan Effendie (1997):

$$
\mathrm{SR}=\frac{\text { Jumlah ikan pada akhir pemeliharaan }}{\text { Jumlah ikan pada awal pemeliharaan }} \times 100
$$

Perhitungan laju pertumbuhan spesifik (SGR) dihitung meggunakan rumus Effendi (1997):

$$
\text { SGR }=\frac{\text { Ln bobot akhir }- \text { Ln bo bot awal }}{\text { Lama waktu pemeliharaan }} \times 100
$$

Nilai heterosis $(\mathrm{H})$ dihitung pada akhir penelitian. Rumus yang digunakan berdasarkan Tave (1995):

$$
H=\left(F 1-\frac{P 1+P 2}{2}\right):\left(\frac{P 1+P 2}{2}\right) \times 100
$$

di mana:

$$
\begin{array}{ll}
\mathrm{H} & \text { : nilai heterosis }(\%) \\
\mathrm{F} 1 & \text { : keturunan persilangan } \\
\mathrm{P} 1, \mathrm{P} 2 & \text { : populasi tetua }
\end{array}
$$

Pengamatan survival activity index (SAI) dilakukan terhadap 10 ekor larva habis kuning telur. Larva dari setiap persilangan dipelihara sekitar 10-20 hari pada akuarium berukuran $20 \mathrm{~cm} \times 20 \mathrm{~cm} \times 20 \mathrm{~cm}$, tanpa diberi pakan, kemudian diamati lama larva bertahan sampai keseluruhan larva mati. Rumus yang digunakan berdasarkan Matsuo et al. (2006):

$$
\mathrm{SAI}=\frac{1}{\mathrm{~N}} \sum_{\mathrm{i}=1}^{\mathrm{k}}(\mathrm{N}-\mathrm{hi}) \mathrm{xi}
$$

di mana:

$\mathrm{N}=$ jumlah larva awal

$\mathrm{Hi}=$ akumulasi kematian pada hari $\mathrm{i}$

$\mathrm{l}=1-\mathrm{k}$

$\mathrm{K}=$ hari terjadi kematian total

Pengamatan abnormalitas dalam penelitian ini meliputi bentuk kepala, bentuk tubuh, dan bentuk ekor. Perhitungan yang dilakukan untuk mengetahui besarnya abnormalitas, yaitu:

$$
\text { Abnormalitas }=\frac{\text { Jumlah larva abnormal }}{\mathrm{t} \text { jumlahlarva normal }} \times 100
$$

Pengamatan parameter kualitas air yang diamati dalam penelitian ini adalah suhu, kadar oksigen terlarut (DO) diukur dengan al at HANNA HI 9829, dan pH diukur dengan alat HANNA HI 98129. Pengamatan kualitas air dilakukan dan dihitung dalam penelitian ini setiap minggu pagi pukul 05.00 WIB dan sore 16.00 WIB.

Parameter yang diamati adalah derajat pembuahan (fertilization rate), derajat penetasan telur (hatching rate), laju pertumbuhan spesifik (specific growth rate), sintasan (survival rate), nilai heterosis, indeks ketahanan hidup (survival activity index) dan abnormalitas larva. Analisis statistik yang dilakukan meliputi uji normalitas, uji homogenitas, dan analisis ragam. Apabila terdapat pengaruh yang nyata dari perlakuan, maka dilakukan uji wilayah ganda Duncan untuk mengetahui perbedaan dari kesembilan perlakuan yang dibantu dengan aplikasi M icrosoft Excel dan SPSS 25. SAI, Kualitas air dan abnormalitas dijelaskan secara deskriptif dengan membandingkan nilai antar perlakuan, serta ditunjang dengan referensi dari hasil penelitian terdahulu. 


\section{HASIL DAN BAHASAN}

Derajat pembuahan terbaik dihasilkan dari hibridisasi Ts $><\mathrm{Td}, \mathrm{Td}><\mathrm{Ts}, \mathrm{Td}><\mathrm{Tt}$ dan berbeda nyata dengan hibrida lainnya $(P<0,05)$. Daya tetas telur terbaik dihasilkan dari hibridisasi $\mathrm{Td}><$ $\mathrm{Ts}, \mathrm{Td}><\mathrm{Tt}, \mathrm{Ts}><\mathrm{Tt}, \mathrm{Tt}><\mathrm{Ts}$ dan berbeda nyata dengan hasil lainnya $(P<0,05)$. Pada laju pertumbuhan spesifik bobot, hasil terbaik diperoleh pada hibridisasi $\mathrm{Ts}><\mathrm{Td}$ dan Tt $><\mathrm{Ts}$, serta berbeda nyata dengan hasil hibrida lainnya $(P<0,05)$. Hasil terbaik pada laju pertumbuhan spesifik panjang diperoleh dari hibridisasi Ts $><$ Td dan berbeda nyata dengan hasil lainnya $(P<0,05)$. Sintasan menunjukkan tidak berbeda nyata antar hibrida yang dihasilkan $(P>0,05)$ (Tabel 2).

Parameter yang berperan penting sebagai indikator kualitas telur salah satunya adalah derajat pembuahan. Derajat pembuahan yang dihasilkan pada penelitian ini lebih tinggi dibanding yang dihasilkan Subagja \& Juli (2014) yang mendapatkan hasil derajat pembuahan pada pemijahan secara buatan ikan Tor berkisar antara $68 \% 80 \%$ Pada persilangan secara resiprokal Tor soro dan Tor douronensis, Radona et al. (2015) mendapatkan hasil derjat pembuahan tertinggi pada persilangan betina Tor soro dengan Tor douronensis dengan nilai 96,88 $\pm 1,67 \%$ dan terendah pada persilangan pure Tor douronensis dengan nilai $81.11 \pm 1.01 \%$ Menurut Effendi et al. (2015), telur dan sperma yang baru dikeluarkan dari tubuh induk pada saat pemijahan, akan mengeluarkan zat kimia yang berguna untuk proses pembuahan. Zat yang dikeluarkan oleh telur dan sperma dinamakan gamone. Gamone yang berasal dari telur ialah gynamone yang berfungsi untuk menarik spermatozoa dari spesies yang sama, gamone yang berasal dari spermatozoa adalah androgamone yang berfungsi untuk menekan aktivitas spermatozoa ketika masih berada di dalam saluran genital ikan jantan.

Secara keseluruhan, derajat penetasan yang dihasilkan adalah sangat baik $(84,33 \pm 2,08 \%-88,00$ $\pm 1,00 \%$. Nilai yang diperoleh dalam penelitian ini hampir sama dengan yang diperoleh Radona et al. (2015) yang mendapatkan derajat penetasan pada persilangan antara Tor soro dengan Tor douronensis yang berkisar antara 78,8\%96,0\% dan penelitan Effendi et al. (2015) yang mendapatkan hasil berkisar antara $80,18 \% 89,19 \%$ pada penetasan telur ikan tor sistem tray. Pada penelitian yang dilakukan Subagja \& Juli (2014) hasil derajat penetasan telur ikan Tor soro berkisar antara 63,3\%76,0\% Menurut Effendi et al. (2015), waktu penetasan telur tergantung pada suhu lingkungan, intensitas cahaya, oksigen terlarut, dan pH. Jika suhu tinggi dan cahaya kuat telur akan cepat menetas, tetapi jika terlalu ekstrem, dan berubah secara mendadak dapat menyebabkan kematian embrio dan kegagalan penetasan. Oksigen terlarut akan memengaruhi jumlah elemen-elemen zat sederhana penyusun embrio, dan $\mathrm{pH}$ dapat memengaruhi kerja enzim chorionase pada telur. Faktor lain yang menyebabkan rendahnya derajat penetasan telur (HR) adalah telur tidak berkembang setelah dibuahi, akibat perubahan kemampuan fisiologis telur saat embriogenesis.

Hasil sintasan yang diperoleh menunjukan nilai yang tinggi untuk semua perlakuan hibridisasi, hal ini

Tabel 2. Derajat pembuahan, derajat penetasan, laju pertumbuhan, dan sintasan hibridisasi interspesifik ikan Tor (T. soro, T. douronensis, dan T. tambroides) secara resiprokal

Table 2. Fertilization, hatching, specific growth, and survival rates of reciprocal interspecific hybridization of Tor species (T. soro, T. douronensis, and T. tambroides)

\begin{tabular}{|c|c|c|c|c|c|}
\hline \multirow[b]{2}{*}{$\begin{array}{c}\text { Sumber genetik } \\
\text { induk } \\
\text { Genetic resources } \\
\text { of broodstock }\end{array}$} & \multicolumn{5}{|c|}{ Parameter (Parameters) ( $\%$} \\
\hline & $\begin{array}{c}\text { Derajat } \\
\text { pembuahan } \\
\text { Fertilization rate }\end{array}$ & $\begin{array}{c}\text { Derajat } \\
\text { penetasan } \\
\text { Hatching rate }\end{array}$ & $\begin{array}{l}\text { Laju pertumbuhan } \\
\text { spesifik bobot } \\
\text { Weight specific } \\
\text { growth rate }\end{array}$ & $\begin{array}{l}\text { Laju pertumbuhan } \\
\text { spesifik bobot panjang } \\
\text { Lenght specific } \\
\text { growth rate }\end{array}$ & $\begin{array}{l}\text { Sintasan } \\
\text { Survival rate }\end{array}$ \\
\hline $\mathrm{Ts}><\mathrm{Td}$ & $91.66 \pm 4.50^{a}$ & $84.33 \pm 2.08^{b}$ & $5.62 \pm 0.17^{\mathrm{a}}$ & $1.79 \pm 0.11^{\mathrm{a}}$ & $81.66 \pm 3.51^{\mathrm{a}}$ \\
\hline $\mathrm{Td}><\mathrm{Ts}$ & $93.66 \pm 1.15^{\mathrm{a}}$ & $88.00 \pm 1.00^{\mathrm{a}}$ & $5.12 \pm 0.01^{b}$ & $1.11 \pm 0.03^{b}$ & $83.66 \pm 1.52^{\mathrm{a}}$ \\
\hline $\mathrm{Td}><\mathrm{Tt}$ & $92.33 \pm 2.51^{\mathrm{a}}$ & $85.77 \pm 2.08^{\mathrm{ab}}$ & $5.10 \pm 0.09^{b c}$ & $1.12 \pm 0.02^{c}$ & $83.66 \pm 0.57^{\mathrm{a}}$ \\
\hline $\mathrm{Ts}><\mathrm{Tt}$ & $87.33 \pm 3.05^{b}$ & $85.33 \pm 3.05^{\mathrm{ab}}$ & $5.44 \pm 0.06^{\mathrm{a}}$ & $1.41 \pm 0.05^{b}$ & $83.66 \pm 2.30^{\mathrm{a}}$ \\
\hline $\mathrm{Tt}><\mathrm{Ts}$ & $87.33 \pm 4.04^{b}$ & $86.00 \pm 3.60^{\mathrm{ab}}$ & $5.45 \pm 0.14^{\mathrm{ab}}$ & $1.11 \pm 0.06^{c}$ & $86.00 \pm 3.60^{\mathrm{a}}$ \\
\hline $\mathrm{Tt}><\mathrm{Td}$ & $86.33 \pm 2.08^{b}$ & $84.33 \pm 2.08^{b}$ & $5.07 \pm 0.10^{b c}$ & $1.07 \pm 0.05^{c}$ & $83.66 \pm 2.30^{\mathrm{a}}$ \\
\hline
\end{tabular}

Keterangan:Nilai yang diikuti huruf superskrip sama pada kolom yang sama menunjukkan tidak berbeda nyata $(P>0,05)$ Note: Values within the same column with the same superscript letter are not significantlydifferent $(P>0.05)$ ) 
menunjukkan keberhasilan hibridisasi dalam menghasilkan benih yang didukung ketersediaan lingkungan yang memadai. Karakter sintasan dapat dipengaruhi oleh faktor lingkungan, ketersediaan pakan, dan kualitas media pada saat pemeliharaan. Abnormalitas yang terjadi pada larva ikan menyebabkan organ-organ tubuh ikan tidak dapat berkembang dengan sempurna. Hal ini berdampak pada rendahnya tingkat sintasan larva (Aidil et al., 2016). Nilai heterosis merupakan indikasi keberhasilan program hibridisasi. Nilai heterosis yang dihitung meliputi adalah derajat pembuahan, derajat penetasan telur, laju pertumbuhan spesifik, dan sintasan. Secara keseluruhan, nilai heterosis yang diperoleh tergolong rendah. Nilai derajat pembuahan telur dan daya tetas telur, seluruh nilai heterosis adalah negatif dengan rata-rata nilai $-5,39 \%$ dan $-6,72 \%$ Nilai heterosis laju pertumbuhan spesifik bobot sebesar 3,07\%dengan nilai tertinggi diperoleh pada hibridisasi $\mathrm{f}$ Ts $><\mathrm{mTd}$ dengan nilai 8,31. Rata-rata nilai heterosis specific growth rate (SGR) panjang adalah $-11,69 \%$ nilai heterosis terendah diperoleh pada hibridisasi $f$ $\mathrm{Td}><$ mTs dengan nilai sebesar $-30,27 \%$ Nilai heterosis karakter sintasan (SR) rata-rata sebesar $-4,68 \%$ nilai terendah dihasilkan pada hibridisasi f $\mathrm{Td}><\mathrm{m}$ $T$ t dan $\mathrm{f} T \mathrm{t}><\mathrm{mTd}$ dengan nilai sebesar $-6,17$. Hal ini menunjukkan bahwa hibridisasi dua arah dari tiga spesies ikan Tor berpengaruh hanya pada karakter laju pertumbuhan spesifik bobot, sedangkkan pada karakter derajat pembuahan, derajat penetasan, laju pertumbuhan spesifik panjang, dan sintasan, hibridisasi menghasilkan nilai negatif (Gambar 1).
Rendahnya nilai heterosis pada penelitian ini berbanding terbalik dengan yang dilakukan Radona et al. (2015) yang memperoleh nilai heterosis pada hibridisasi ikan Tor soro dengan Tor douronensis dengan nilai heterosis pada karakter panjang sebesar $40,90 \%$ dan bobot dengan nilai heterosis positif sebesar 116,66\%dan 1,26\%pada karakter sintasan. Lebih lanjut dikemukakan bahwa nilai heterosis menerangkan suatu kondisi perbandingan antara rata-rata keturunan dengan rata-rata kedua tetuanya. Pada penelitian yang dilakukan Darmawan \& Tahapari (2017), diperoleh nilai heterosis karakter bobot tubuh, panjang total, laju pertumbuhan spesifik, dan sintasan pada persilangan ikan patin siam dengan patin jambal dengan nilai masing-masing sebesar 46,00\% 11,27\% -6,65\% dan $2,27 \%$ Rendahnya nilai heterosis yang diperoleh sejalan dengan hasil yang diperoleh Arifin \& Kurniasih (2012) pada performa pemijahan tiga stok huna merah yang mendapatkan nilai heterosis untuk karakter panjang dan bobot akhir yang relatif rendah untuk seluruh hasil hibridisasi yang dihasilkan, sedangkan untuk parameter laju pertumbuhan spesifik panjang dan bobot, semua hasil hibridisasi menunjukan hasil negatif, demikian juga pada nilai heterosis ikan nila yang dilakukan Gunadi et al. (2016) yang mendapatkan nilai sebesar $8,49 \% 2,13 \%$ dan $24,44 \%$ untuk karakter bobot, panjang, dan sintasan pada persilangan antara nila nirwana dengan nila biru. Menurut Arifin et al. (2017a), heterosis merupakan penampilan tambahan yang diperlihatkan oleh generasi hibrida di atas ratarata penampilan induknya. Nilai heterosis positif mengindikasikan adanya perbaikan performa benih

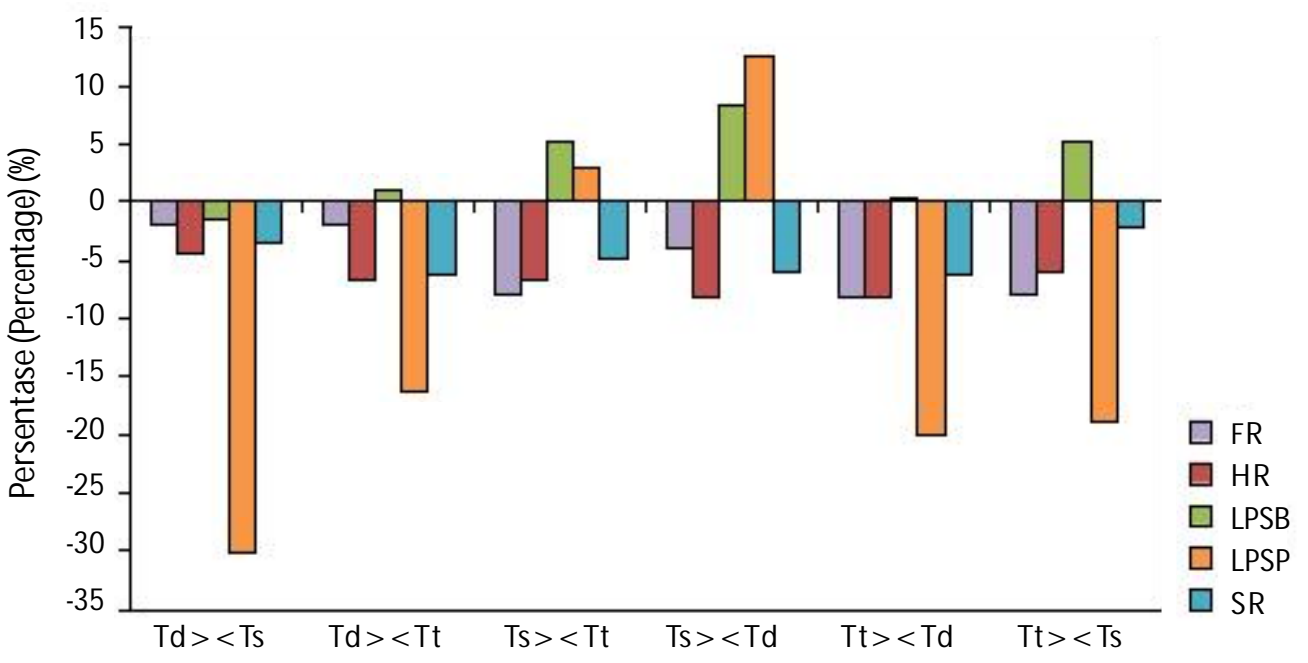

Gambar 1. Nilai heterosis hibridisasi interspesifik ikan Tor (T. soro, T. douronensis, dan $T$. tambroides) secara resiprokal. $F R=$ derajat pembuahan; $H R=$ derajat tetas; $L P S B=$ laju pertumbuhan spesifik bobot; LPSP= laju pertumbuhan spesifik panjang; $S R=$ sintasan.

Figure 1. Heterosis value of reciprocal interspecific hybridization of Tor species (T. soro, T. douronensis, and $\mathbf{T}$. tambroides). $F R=$ fertilization rate; $H R=$ hatching rate; $L P S B=$ specific growth rate of weight; $L P S P=$ specific growth rate of length; $S R=$ survival rate 
dari induknya, sedangkan nilai heterosis negatif menunjukkan adanya penurunan performa hibrida. Pemilihan sumber genetik yang tepat akan meningkatkan kualitas fenotipe heterozigot hibridisasi. Secara genetis, hibridisasi mampu menambah keragaan genetik, serta menyatukan keunggulan dari masing-masing spesies kepada keturunan hasil hibridisasi. Akan tetapi, keragaan genetik yang tinggi belum tentu menghasilkan benih hasil hibridisasi dengan performa baik, bergantung pada intensitas gen yang memiliki sifat keunggulan. Gen tersebut akan terekspresi secara penuh tidak bergantung pada lingkungan luar. Potensi genetik tidak dapat terekspresi tanpa ada pendukung yang memadai.

Rendahnya nilai heterosis yang dihasilkan dalam penelitian ini bisa juga disebabkan oleh masih tingginya keragaan genetik induk yang digunakan. Cassady et al. (2002) mengemukakan bahwa dalam usaha untuk memperbaiki aktivitas diastatik gen yang memunculkan efek heterosis yang dikehendaki, perlu dilakukan seleksi secara ketat dan berulang pada kedua tetuanya terhadap sifat yang akan digabungkan, untuk memperoleh kedua tetua yang betul-betul baik dalam memunculkan heterosis yang baik pula. Efek heterosis positif yaitu rata-rata penampilan suatu karakter keturunan hasil hibridisasi melebihi rata-rata penampilan kedua tetuanya, sedangkan efek heterosis negatif adalah rata-rata penampilan suatu karakter keturunan hasil hibridisasi yang lebih rendah dari ratarata penampilan kedua tetuanya. Penampilan yang berhubungan dengan produksi pada umumnya heterosis positif, sedangkan penampilan reproduksi pada umumnya heterosis efek negatif.

Nilai SAl tertinggi diperoleh pada larva hasil hibridisasi Ts $><$ Tt $(271,5)$ dan nilai terendah diperoleh dari hasil hibridisasi Td $><$ Ts $(55,0)$. Menurut Cahyanti (2018), SAI merupakan indikator efektif kebugaran tubuh larva, namun pengukurannya membutuhkan waktu yang relatif panjang, untuk jenis ikan Tor antara 10-20 hari. Aktivitas enzim, perilaku, dan karakteristik larva dianggap memiliki korelasi dengan SAI dan sintasan. Larva dengan SAI rendah $(8,8-$ $21,5)$ memiliki tubuh lebih panjang, konsumsi oil globul lebih besar, kecepatan dan frekuensi berenang, serta aktivitas enzim esterase yang lebih tinggi dibandingkan larva dengan SAI lebih tinggi $(26,0-41,8)$ (Tabel 3).

Abnormalitas larva yang dihasilkan menunjukkan tidak berbeda nyata antar hibrida yang dihasilkan $(P>0,05)$ (Tabel 4).
Terjadinya larva abnormal dapat disebabkan berbagai faktor, dalam penelitian ini diduga abnormalitas disebabkan perbedaan ukuran antara kepala sperma dan lubang mikrofil telur sehingga semakin sesuai ukuran keduanya, maka peluang terjadinya abnormal pada larva akan menurun. Abnormalitas merupakan keadaan di mana ikan memiliki kondisi/bentuk tubuh yang menyimpang dari keadaan normal atau tidak seperti seharusnya atau cacat (Ardhardiansyah et al., 2017). Abnormalitas larva diduga terjadi karena adanya proses penyimpangan pada saat proses pembelahan sel pada saat embriogenesis atau bahkan larva yang cacat setelah terjadinya penetasan, atau dapat juga terjadi akibat proses pencampuran saat pembuahan dilakukan.

Hasil hibridisasi sangat bervariasi mulai dari ketidakmampuan spesies untuk melakukan kawin silang, sampai menghasilkan larva yang akan menjadi anak ikan yang fertil. Faktor lain yang diduga menyebabkan abnormalitas adalah perbedaan bentuk dan ukuran atau komposisi gen-gennya. Jumlah kromosom satu spesies yang sama dengan spesies lain dapat memiliki perbedaan bentuk, ukuran, dan komposisi gen-gennya. Makin jauh hubungan kekerabatan suatu organisme, makin besar kemungkinan perbedaan jumlah, bentuk, dan susunan kromosomnya (Ville \& Dethier, 1971).

Salah satu faktor yang menunjang keberhasilan proses pemeliharaan larva ikan Tor adalah kualitas air. Berdasarkan hasil pengamatan terhadap suhu, pH, dan oksigen tidak menunjukkan perbedaan kualitas air yang tinggi antar perlakuan dan berada pada kisaran optimal yang mampu ditoleransi (Tabel 5). Hal ini menunjukkan bahwa perbedaan parameter uji yang dihasilkan dalam penelitian ini bukan karena adanya perbedaan kualitas air media selama pemeliharaan melainkan akibat dari perbedaan sumber genetik induk dalam hibridisasi.

\section{KESIMPULAN}

Sampai fase pascalarva, hibridisasi interspesifik tiga spesies ikan Tor tidak menunjukkan pengaruh nyata terhadap peningkatan karakter derajat pembuahan, derajat penetasan, laju pertumbuhan spesifik panjang dan bobot, serta sintasan.Nilai heterosis untuk semua karakter uji adalah negatif kecuali pada karakter laju pertumbuhan spesifik bobot. Hibridisasi berdampak pada meningkatnya jumlah larva abno rmal yang dihasilkan dibandingkan tetuanya (purebreed). 
Tabel 3. Indeks ketahanan hidup hibrida interspesifik ikan Tor (T. soro, T. douronensis, dan T. tambroides) secara resiprokal

Table 3. Survival activity index of reciprocal interspecific hybridization of Tor species (T. soro, T. douronensis, and T. tambroides)

\begin{tabular}{cc}
\hline $\begin{array}{c}\text { Sumber genetik induk } \\
\text { Genetic resources of broodstock }\end{array}$ & $\begin{array}{c}\text { Indeks ketahanan hidup } \\
\text { Survival activity index }\end{array}$ \\
\hline$T s><\mathrm{Td}$ & 233.8 \\
$\mathrm{Td}><\mathrm{Ts}$ & 55.0 \\
$\mathrm{Ts}><\mathrm{Tt}$ & 271.5 \\
$\mathrm{~T} t><\mathrm{Ts}$ & 175.0 \\
$\mathrm{Td}><\mathrm{Tt}$ & 63.8 \\
$\mathrm{Tt}><\mathrm{Td}$ & 192.7 \\
\hline
\end{tabular}

Tabel 4. Hasil pengamatan abnormalitas hibrida interspesifik ikan Tor (T. soro, T. douronensis, dan T. tambroides) secara resiprokal

Table 4. Abnormalities observation on reciprocal interspecific hybridization of Tor species (T. soro, T. douronensis, and T. tambroides)

\begin{tabular}{ccc}
\hline $\begin{array}{c}\text { Sumber genetik induk } \\
\text { Genetic resources } \\
\text { of broodstock }\end{array}$ & $\begin{array}{c}\text { Jumlah larva abnormal } \\
\text { Abnormal number } \\
\text { of larvae } \%\end{array}$ & $\begin{array}{c}\text { Bagian tubuh abnormal } \\
\text { Abnormal body parts }\end{array}$ \\
\hline $\mathrm{Ts}><\mathrm{Td}$ & $10.0 \pm 10.00^{\mathrm{a}}$ & Tubuh dan ekor (Body and tail) \\
$\mathrm{Td}><\mathrm{Ts}$ & $13.3 \pm 5.77^{\mathrm{a}}$ & Tubuh dan ekor (Body and tail) \\
$\mathrm{Ts}><\mathrm{Tt}$ & $16.7 \pm 5.77^{\mathrm{a}}$ & Tubuh, ekor, dan kepala (Body, tail, and head) \\
$\mathrm{Tt}><\mathrm{Ts}$ & $13.3 \pm 11.55^{\mathrm{a}}$ & Tubuh dan ekor (Body and tail) \\
$\mathrm{Td}><\mathrm{Tt}$ & $13.3 \pm 5.77^{\mathrm{a}}$ & Tubuh dan ekor (Body and tail) \\
$\mathrm{Tt}><\mathrm{Td}$ & $13.3 \pm 5.77^{\mathrm{a}}$ & Tubuh dan ekor (Body and tail) \\
\hline
\end{tabular}

Tabel 5. Nilai kualitas air di akuarium selama penelitian

Table 5. Water quality variation in the aquarium during the experiment

\begin{tabular}{lccc}
\hline $\begin{array}{c}\text { Sumber genetik induk } \\
\text { Genetic resources } \\
\text { of broodstock }\end{array}$ & \multicolumn{3}{c}{ Parameter (Parameters) } \\
\cline { 2 - 4 } & $\begin{array}{c}\text { Suhu } \\
\text { Temperature } \mathbf{~}^{\circ} \mathbf{C} \text { ) }\end{array}$ & pH & $\begin{array}{c}\text { Oksigen terlarut } \\
\text { Dissolved oxygen (mg/L) }\end{array}$ \\
\hline $\mathrm{Ts}><\mathrm{Td}$ & $23.74-25.96$ & $6.44-7.90$ & $7.73-8.73$ \\
$\mathrm{Td}><\mathrm{Ts}$ & $23.41-26.38$ & $6.43-7.33$ & $7.81-8.41$ \\
$\mathrm{Ts}><\mathrm{Tt}$ & $23.76-25.83$ & $6.28-8.44$ & $7.21-8.73$ \\
$\mathrm{Tt}><\mathrm{Ts}$ & $23.47-25.63$ & $6.62-7.15$ & $7.82-8.45$ \\
$\mathrm{Td}><\mathrm{Tt}$ & $23.47-26.20$ & $6.32-7.31$ & $7.91-8.36$ \\
$\mathrm{Tt}><\mathrm{Td}$ & $23.54-25.68$ & $6.51-7.24$ & $7.89-8.44$ \\
Acuan & $22-32$ & $6-8$ & $>4$ \\
References & (Arifin et al ., 2019) & (Arifin et al ., 2019) & (Arifin et al ., 2019) \\
\hline
\end{tabular}

\section{UCAPAN TERIMA KASIH}

Ucapan terima kasih disampaikan kepada Bapak Nurhidayat sebagai Kepala BRPBATPP Bogor, Ibu Wahyulia Cahyanti, Bapak Jojo Subagja, Heppy Aprilistianto, Ujang Heri Heryana, dan seluruh staf Instalasi Riset Plasma Nutfah Perikanan Air Tawar, Cijeruk atas bantuan teknis yang diberikan.

\section{DAFTAR ACUAN}

Aidil, D., Zulfahmi, I., \& Muliari, M. (2016). Pengaruh suhu terhadap derajat penetasan telur dan perkembangan larva ikan lele Sangkuriang (Clarias Gariepinus Var. Sangkuriang). Jurnal Edukasi dan Sains Biologi, 5(1), 30-33. 
Ardhardiansyah., Subhan, U., \& Yustiati, A. (2017). Embriogenesis dan Karakteristik Larva Persilangan Ikan Patin Siam (Pangasius hypophthalmus) Jantan dengan Ikan baung (Hemibagrus nemurus) Betina. Jurnal Perikanan dan Kelautan, 7(2), 17-27.

Arifin, O.Z., Imron, Aseppendi, Hendri, A., Muslim, N., \& Yani, A. (2017a). Hibridisasi intraspesifik antar dua populasi ikan gurami Galunggung (Osphronemus goramy, Lacepede, 1801). Jurnal Riset Akuakultur, 12(4), 315-323.

Arifin, 0.Z., Imron, Muslim, N., Hendri, A., Aseppendi, \& Yani, A. (2017b). Karakteristik fenotipe dan genotipe ikan gurami, Osphronemus goramy, Galunggung putih dan hibridanya strain Galunggung hitam. Jurnal Riset Akuakultur, 12(2), 99-110.

Arifin 0.Z. \& Kurniasih, T. (2013). Keragaan pemijahan antar tiga stok udang huna merah (Cherax quadricarinatus von Martens). Berita Biologi, 12(1), 97-106.

Arifin, O.Z., Subagja, J., Asih, S., \& Kristanto, A.H. (2019). Budidaya ikan dewa. Bogor: IPB Pres, $98 \mathrm{hlm}$.

Cahyanti, W. (2018). Karakteristik truss morfometrik, genotipe dan reproduksi tiga spesies ikan potensial budidaya dalam genus Tor untuk pemuliaan genetik. Tesis. Repository IPB. Bogor.

Cassady, P.J, Yung, L.D., \& Leymaster, K.A. (2002). Heterosis and recombinant effects on pig reproductive traits. Journal Animal Science, 20(9), 2303-2315.

Darmawan, J. \& Tahapari, E. (2017). Ferforma pertumbuhan, koefisien variasi, dan heterosis hasil persilangan ikan patin (Pangasius sp.) pada tahap pendederan II. Jurnal Riset Akuakultur, 12(1), 21-28.

Effendie, M.I. (1997). Biologi perikanan. Yogyakarta: Yayasan Pustaka Nusatama, $163 \mathrm{hlm}$.

Effendi, E.M., Pratama, I., \& Subagja, J. (2015). Teknik inkubasi telur menggunakan sistem tray bertingkat untuk meningkatkan daya tetas telur ikan semah
(Tor douronensis). Ekologia: Jurnal Ilmiah IImu Dasar dan Lingkungan Hidup,15(1), 14-21.

Gunadi, B., Robisalmi, A., \& Setyawan, P. (2016). Performa pertumbuhan dan estimasi nilai heterosis juvenil ikan nila (Orochromis niloticus), ikan nila biru (Oreochromis aureus) dan persilangannya yang dipelihara di kolam air tawar. Prosiding Forum Inovasi Teknologi Akuakultur, hIm. 571-577.

Matsuo, Y., Kasahara, Y., Hagiwara, A., Sakakura, Y., \& Arakawa, T. (2006). Evaluation of Larval Quality of Viviparous Scorpionfish Sebastiscus marmoratus. Fisheries Science, 72, 948-954.

Qudus, R.R., Lili, W., \& Rosidah. (2012). Pengaruh padat penebaran yang berbeda terhadap tingkat kelangsungan hidup dan pertumbuhan benih ikan kancra (Tor soro). Jurnal Ilmu Hewani Tropika, 5(2), 88-94.

Radona, D., Subagja, J., \& Arifin, O.Z. (2015). Performa reproduksi induk dan pertumbuhan benih ikan Tor hasil persilangan (Tor soro dan Tor douronensis) secara resiprokal. Jurnal Riset Akuakultur, 10(3), 335-343.

Rahman, M.A., Arshad, A., Marimuthu, K., Ara, R., \& Amin, S.M.N. (2013). Inter-specific hybridization and its potential for aquaculture of fin fishes. Asian Journal of Animal and Veterinary Advances, 8(2), 139-153.

Subagja, J. \& Juli, M. (2014). Pengembangan teknologi pembenihan ikan Tor soro (Tor soro) di Balai Benih Ikan Sentral, Kerinci Jambi. Prosiding Forum Inovasi teknologi Akuakultur, hlm. 875-883.

Tave, D. (1995). Selective breeding programmes for medium-sized fish farms. Rome: FAO Fisheries Technical Paper No. 352, 122 pp.

Ville, C. \& Dethier, V.G. (1971). Biological principles and process. Philadelphia: W.B. Sounders, p. 217-219.

Yustysi, D.P., Basuki, F., \& Susilowati, T. (2016). Analisis karakter reproduksi dan performa benih pendederan I, Ikan nila Pandu F6 dengan ikan nila Nilasa (Oreochromis niloticus) secara resiprokal. Journal of Aquaculture M anagement and Technology, 5(1), 116-123. 